American Journal of Environmental Sciences 7 (2): 108-118, 2011

ISSN 1553-345X

(C) 2010 Science Publications

\title{
Factors Affecting the Oxygenation Capacity of Disc Aerators in an Oxidation Ditch System
}

\author{
Abdel Ghaly and Skai Edwards \\ Department of Process Engineering and Applied Sciences, \\ Dalhousie University, Halifax, Nova Scotia, Canada
}

\begin{abstract}
Problem statement: The use of aerobic biological methods for the treatment of livestock wastes has resulted in a proliferation of mechanical aeration devices to accomplish the desired treatment. The oxidation ditch system with disc aerators is among the aerobic systems that have been used to treat livestock waste. The main objectives of this study were to investigate the effects of various disc design parameters and system operational parameters on the oxygen transfer coefficient and to study the physical phenomenon of oxygen transfer using high speed movie techniques. Approach: A bench-scale oxidation ditch with a disc aerator was used to conduct a series of experiments to determine the effects of immersion depth $(2.5-7.5 \mathrm{~cm})$, disc speed $(50-250 \mathrm{rpm})$, disc thickness $(0.32-2.55 \mathrm{~cm})$, hole diameter $(0.00-1.92 \mathrm{~cm})$ and number of rotating discs $(1-2)$ on the oxygen transfer coefficient. The unsteady state method with sodium sulfite oxidation was used to deoxygenate the water and the dissolved oxygen concentration was measured with time. Results: The disc speed had the most significant effect on $\mathrm{K}_{\mathrm{L}}$ a with the immersion depth and hole diameter both showing strong effects and the disc thickness showing less effect. The effect of adding a second disc was comparable to using a single disc of double the thickness at lower speeds while at speeds higher than $200 \mathrm{rpm}$ doubling the thickness of a single disc had less effect than a second disc. Conclusion: The highest oxygen transfer $\left(1.526 \mathrm{~min}^{-1}\right)$ was achieved using two coaxial discs with a disc speed of $250 \mathrm{rpm}$, a disc thickness of $0.64 \mathrm{~cm}$, a hole diameter of $1.92 \mathrm{~cm}$ and an immersion depth of $7.5 \mathrm{~cm}$. Bubble aeration and eddy aeration were the most prevalent mechanisms of oxygen transfer in the oxidation ditch while surface aeration played a relatively small role in oxygen transfer.
\end{abstract}

Key words: Aeration device, oxygen transfer coefficient, oxygenation capacity, disc aerator, hole diameter, immersion depth, disc thickness, oxygen transfer, oxidation ditch

\section{INTRODUCTION}

, however, be more fruitful to try to improve the Aerobic biological methods have been successfully used to treat livestock and poultry wastes (Kargi et al., 1980; Bicudoe et al., 1995; Carta, et al. 1999; Tiquia et al., 2002; Juteau et al. 2004; Mohaibes and HeinonTanski, 2004; Zhu et al., 2004; Zhang et al., 2006). The main functions of any aeration device are to: (a) supply a sufficient quantity of oxygen to the liquid medium to maintain aerobic conditions, (b) circulate the liquid to keep solids in suspension and avoid settling, (c) distribute the oxygenated liquid throughout the liquid body to avoid anaerobic zones and (d) keep good contact between the microbial cells, nutrients and dissolved oxygen to ensure efficient biodegradation of the organic matter (Carta et al., 1999; Fritsche and Hofrichter, 2008). From the viewpoint of the livestock producer, the aeration process should be accomplished

Corresponding Author: Abdel Ghaly, Department of Process Engineering and Applied Sciences, Dalhousie University, alifax, Nova Scotia, Canada at the least cost per kilogram of waste treated. The oxidation ditch system has been successfully used for treating animal waste (Loehr, 1971; Murray et al., 1975; Ghaly, 1982; Ushikubo et al., 1991; Otawa et al., 2006). The ditch essentially consists of a closed loop, open channel in which liquid circulation and oxygen input are maintained by a mechanical device such as paddle, brush, or disc aerators. The disc aerator described by Drews et al. (1972) and Ghaly (1982) has certain advantages over the brush and paddle wheel rotors with regard to foam generation. However, the oxygenation capacity of an individual disc is limited and the use of a number of discs on the rotating shaft was suggested in order to allow for a wider range of oxygenation capacities (Drews et al., 1972; Ogilvie and Kingsbury, 1974; Ghaly, 1982; Nemerow, 2007). It wouldoxygenation capacity of a single disc aerator rather than merely use large numbers of discs. 

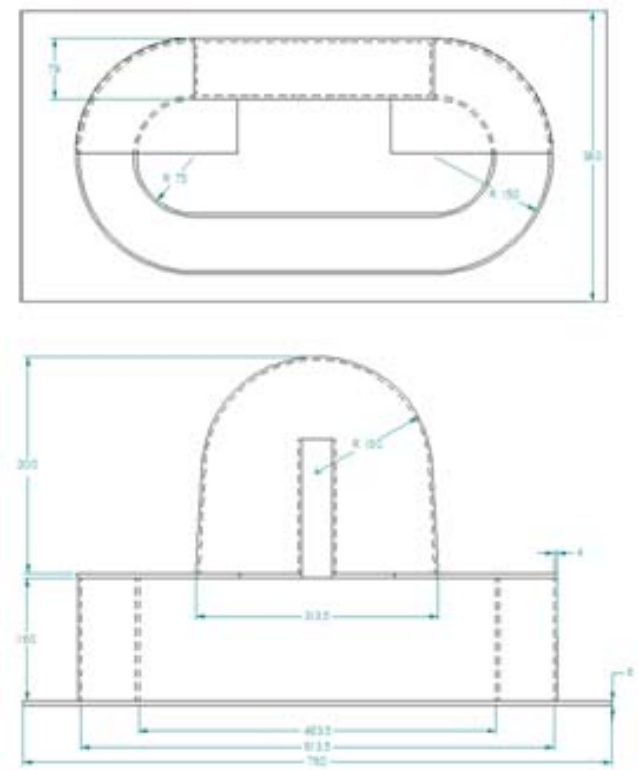

Fig. 1: Schematic diagram of the continuous culture apparatus

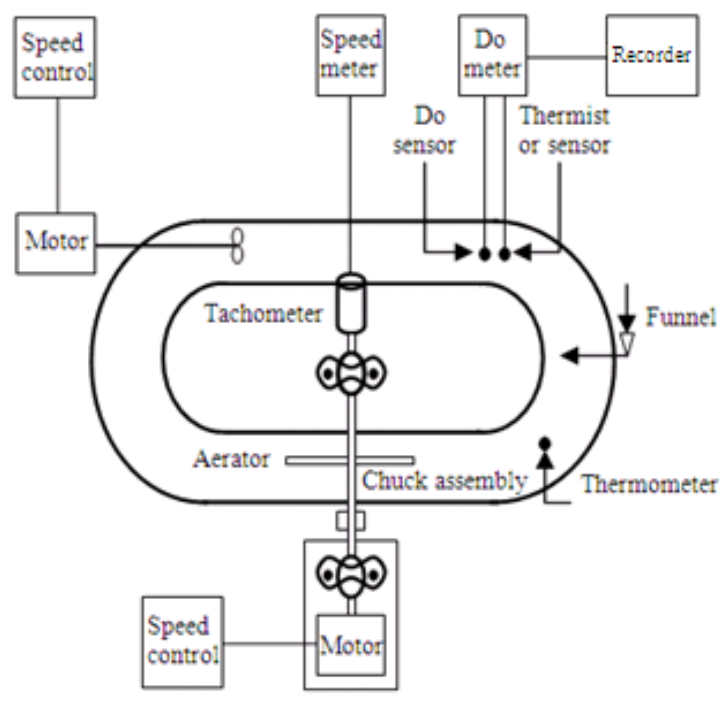

Fig. 2: Dimensions of oxidation ditch and aeration hood

The objectives of this study were to investigate the effects of various disc design parameters and system operation parameters on the oxygenation capacity of the disc aerator.

Experimental Apparatus: A bench scale oxidation ditch system (Fig. 1) equipped with a disc aerator was used to gain an understanding of the phenomenon of oxygen transfer and to study the effects of the disc design parameters and system operation parameters on the rate of oxygen transfer in deionized water. The equipment included a ditch, a hood, aerator discs, a motor and a speed controller.

A race track type oxidation ditch was constructed of acrylic plastic (Fig.2). The thickness and height of the ditch walls were 0.4 and $16.0 \mathrm{~cm}$, respectively. The walls of the ditch were gluedonto a $76 \times 38 \mathrm{~cm}$ acrylic plate of $0.6 \mathrm{~cm}$ thickness. The inner and outer diameters of the circular part of the ditch were 15 and $30 \mathrm{~cm}$, respectively. The length of theditch side was $31.35 \mathrm{~cm}$, the ditch area was $1000 \mathrm{~cm}^{2}$ and the volume was $16000 \mathrm{~cm}^{3}$.

The aerator discs were fabricated of acrylic plastic. The diameter of the discs was $29 \mathrm{~cm}$. Holes were drilled in the outer $7 \mathrm{~cm}$, parallel to the disc axis. The independent variables considered in the design of the discs were: disc thickness, hole diameter and number of holes. Five disc thicknesses $(0.32,0.64,1.28,1.92$ and $2.55 \mathrm{~cm})$ and five hole diameters $(0.00,0.32,0.64,1.28$ and $1.29 \mathrm{~cm}$ ) were studied. A total of twenty five discs were fabricated. The number of holes drilled in the discs were such that all discs had the same perforated area $\left(123 \mathrm{~cm}^{2}\right.$ out of660 $\mathrm{cm}^{2}$ i.e. $\left.19 \%\right)$. This resulted in 1536, 384, 96 and 43 holes per disc for the discs having $0.32,0.64,1.28$ and $1.92 \mathrm{~cm}$ hole diameters, respectively. The aerator was covered with a hood made of acrylic plastic to avoid loss of the ditch contents by splashing.

The disc was mounted on a rotating shaft so that it was partially submerged in the ditch contents. The disc shaft was driven by an adjustable speed (0-500 rpm) electric motor (Steadi-Speed Stirrer No. 14-498A, Fisher Scientific, Montreal, Quebec, Canada). The motor shaft was attached to the disc shaft through a chuck assembly. The disc immersion depth was adjusted by lowering or raising both the drive and disc shafts to the required height using two pieces of Plexiglas of the same thickness $(2.5$ and $5.0 \mathrm{~cm}$ ) under the bearings. A generator tachometer (Servo-Tek Model ST-9540-20, Fisher Scientific, Montreal, Quebec, Canada) was connected to the disc shaft by means of a Tygon tube to measure the speed of rotation.

A general purpose filtering funnel (Kimble 28950 No 10-322E, Fisher Scientific, Montreal, Quebec, Canada), connected to the ditch by a tygon tube, was used to gradually add sodium sulfite and cobalt chloride solutions to the ditch. An impeller of $31 \mathrm{~cm}$ length and $4.4 \mathrm{~cm}$ propeller diameter, connected to a stirring apparatus (Dyna-Mix Model 43, Fisher Scientific, Montreal, Quebec, Canada) with the propeller at the 
mid-depth of the ditch, was used to circulate and mix dissolved oxygen was measured by a polarographic electrode (Beckman $39553 \quad \mathrm{O}_{2}$ Sensor, Fisher Scientific, Montreal, Quebec, Canada) connected to a dissolved oxygen meter (Beckman Fieldlab Oxygen Analyzer Model 1008, Fisher Scientific, Montreal, Quebec, Canada).

A Locam $16 \mathrm{~mm}$ High Speed Motion Picture Camera (500 frames per second) was used to film the movement of bubbles during the aeration process.

Experimental design: Three independent disc design variables (disc thickness, hole diameter and number of holes) and two operational variables (disc immersion depth, disc rotational speed and number of coaxially mounted discs) were considered for optimization of the oxygenation capacity of the system. However, a complete factorial experiment including all six factors was considered impractical in view of the scope and time available for the completion of this study. Therefore, three sets of experiments were carried out.

In the first set of experiments, the oxygen transfer coefficient $\left(\mathrm{K}_{\mathrm{L}} \mathrm{a}\right)$ was determined at all combinations of three immersion depths $(2.5,5.0$ and $7.5 \mathrm{~cm})$ and five disc speeds (50,100,150, 200 and $250 \mathrm{rpm})$ for one disc having a thickness of $0.64 \mathrm{~cm}$ and 48 holes of 1.28 $\mathrm{cm}$ diameter. The results were compared with those obtained when using a nonperforated disc of the same thickness.

After having eliminated the immersion depth as an independent variable, a second set of experiments was conducted to study the effects of disc speed, disc thickness and hole diameter on $\mathrm{K}_{\mathrm{L}} \mathrm{a}$. In this set, a 5 x 5 x 5 factorial experiment, laid down in a completely randomized block design, was used. Split-split-plot design in two blocks was utilized. The five levels of the hole diameter $(0.00,0.32,0.64,1.28$ and $1.92 \mathrm{~cm})$ were randomly assigned into the main plot units in each block. Then, the five levels of the disc thickness (0.32, $0.64,1.28,1.92$ and $2.55 \mathrm{~cm}$ ) were assigned at random into the sub-plot units in each main plot unit. Finally, the five levels of disc speed (50, 100, 150, 200 and 250 $\mathrm{rpm}$ ) were assigned at random into the sub-sub-plot units in each sub-plot unit. The two blocks were used as replicates resulting in a total of 250 treatments.

In the third set of experiments, the effect of using more than one aerator disc on the rotating shaft on $\mathrm{K}_{\mathrm{L}} \mathrm{a}$ was studied. Because of the limited width of the ditch $(7.5 \mathrm{~cm})$, it was only feasible to install a maximum of two discs, spaced at $2.5 \mathrm{~cm}$ on the rotating shaft. This was done for two disc thicknesses $(0.32$ and $0.64 \mathrm{~cm})$. The immersion depth of $7.5 \mathrm{~cm}$ was maintained during the experiments. $\mathrm{K}_{\mathrm{L}} \mathrm{a}$ values were obtained for these two discs at five disc speeds (50, 100, 150, 200 and 250 rpm). The results were compared with those obtained the ditch contents during the deoxygenation process. when using single discs of the same thickness and single discs of double the thickness.

Experimental procedure: During each experimental run, the ditch contents were aerated, deoxygenated and then reaerated. The unsteady state method with sulfite oxidation described by Ghaly et al. (1988) was used. Initially, the ditch was cleaned thoroughly with tap water and then flushed several times with deionized water before each run. Eleven litres of deionized water were then added to the ditch. The dissolved oxygen meter, recorder and aerator motor were started simultaneously and the temperature and barometric pressure were recorded.

When the saturation concentration $\left(\mathrm{C}_{\mathrm{s}}\right)$ was reached (the oxygen concentration curve became flat), the aerator motor was switched off and $13.8 \mathrm{ml}$ of $0.10 \mathrm{M}$ $\mathrm{Na}_{2} \mathrm{SO}_{3}$ solution (173.8 mg sodium sulfite) and $1.6 \mathrm{ml}$ of $0.01 \mathrm{M} \mathrm{CoCl}{ }_{2} \cdot 6 \mathrm{H}_{2} \mathrm{O}$ solution $(2.2 \mathrm{mg}$ cobalt chloride) were added. These solutions were distributed throughout the oxidation ditch by the impeller. When the water was completely deoxygenated, the impeller motor was shut off and the aerator motor was started. The dissolved oxygen concentration $\left(\mathrm{C}_{\mathrm{L}}\right)$ then increased until it reached the saturation concentration $\left(\mathrm{C}_{\mathrm{s}}\right)$. During a typical experiment, $\mathrm{C}_{\mathrm{L}}$ remained at zero until the excess sodium sulfite had been oxidized, rose rapidly at the beginning and then slowly approached its saturation value again. A typical recorded curve of the entire process of saturation-deoxygenation-reaeration is shown in Fig. 3. Data from the reaeration curves were plotted on semilogarithmic study to determine the $\mathrm{K}_{\mathrm{L}} \mathrm{a}$ values as shown in Fig. 4. $\mathrm{K}_{\mathrm{L}}$ avalues obtained under laboratory conditions were converted to their equivalent values at $20^{\circ} \mathrm{C}-101.3 \mathrm{kPa}$ using the following equations:

$\mathrm{C}_{\mathrm{sp}} \quad=\mathrm{C}_{\mathrm{s}} \mathrm{P}_{\mathrm{ab}} / \mathrm{P}_{\mathrm{at}}$

$\mathrm{K}_{\mathrm{L}} \mathrm{a}_{(20)}=\mathrm{K}_{\mathrm{L}} \mathrm{a}_{(\mathrm{T})}(1.24)^{20-\mathrm{t}}$

Slope $=-\mathrm{K}_{\mathrm{L}} \mathrm{a}$

Where:

$\mathrm{C}_{\mathrm{s}}=$ Concentration of $\mathrm{O}_{2}$ in water at laboratory barometric pressure $\left(\mathrm{mg} \mathrm{L}^{-1}\right)$

$\mathrm{C}_{\mathrm{sp}}=$ Concentration of $\mathrm{O}_{2}$ in water at standard atmospheric pressure $\left(\mathrm{mg} \mathrm{L}^{-1}\right)$

$\mathrm{P}_{\mathrm{ab}}=$ Absolute laboratory barometric pressure $(\mathrm{kPa})$

$\mathrm{P}_{\mathrm{at}}=$ Standard atmospheric pressure $(\mathrm{kPa})$

$\mathrm{K}_{\mathrm{L}} \mathrm{a}_{(20)}=$ The overall volumetric oxygen transfer coefficient at $20^{\circ} \mathrm{C}$

$\mathrm{K}_{\mathrm{L}} \mathrm{a}_{(\mathrm{t})}=$ The measured overall volumetric oxygen transfer coefficient

$\mathrm{T}=$ The water temperature $\left({ }^{\circ} \mathrm{C}\right)$ 


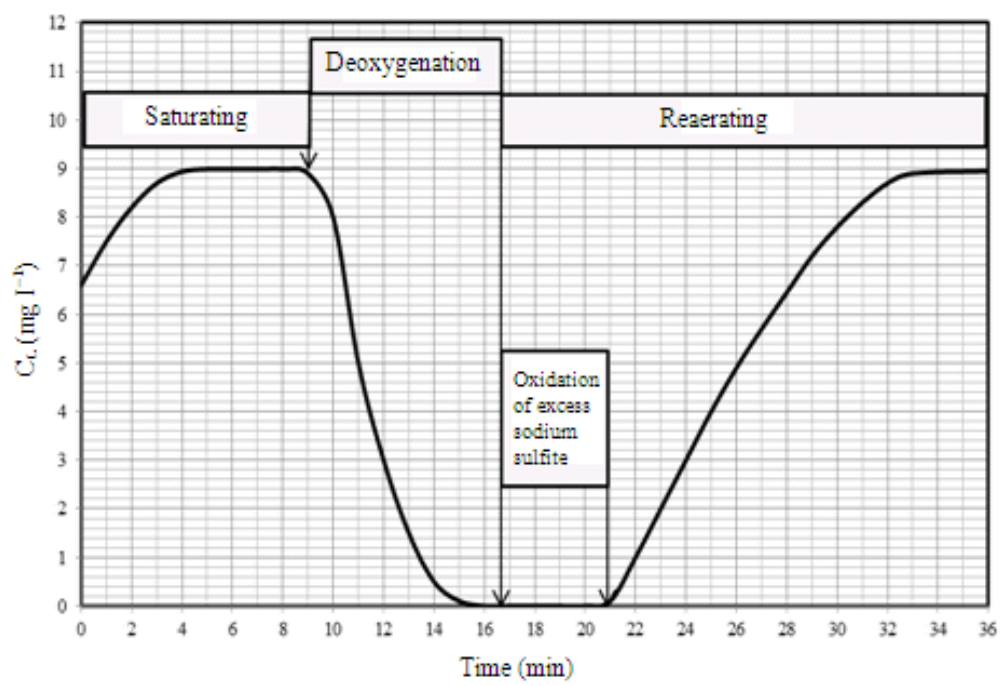

Fig. 3: The oxygen concentration curve obtained during a typical experimental run

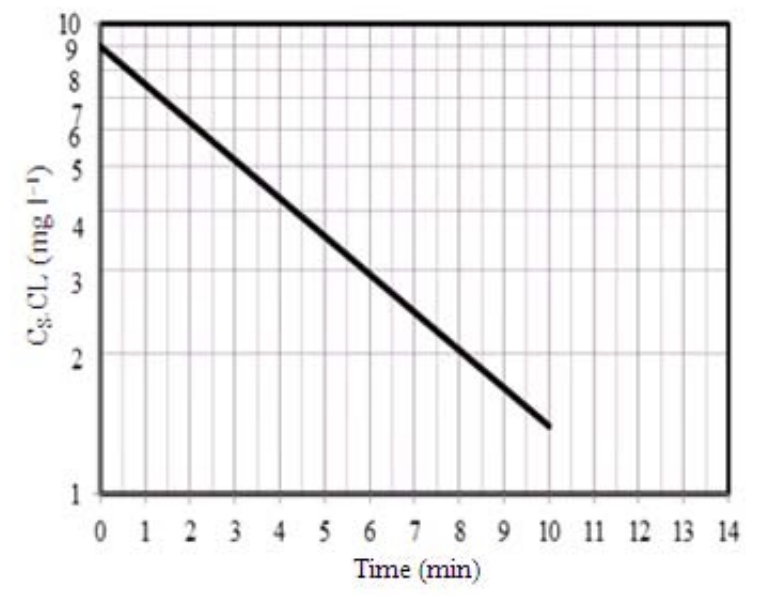

Fig. 4: Determination of $\mathrm{K}_{\mathrm{L}} \mathrm{a}$

Equation 1 was used to correct the value of $\mathrm{C}_{\mathrm{s}}$ and equation 2 was used to correct the value of $\mathrm{K}_{\mathrm{L}} \mathrm{a}$. This left $\mathrm{K}_{\mathrm{L}}$ a exclusively a function of the design parameters of the disc aerator in the oxidation ditch.

\section{RESULTS}

Immersion depth experiments: The effect of immersion depth on $\mathrm{K}_{\mathrm{L}} \mathrm{a}$ was studied at various disc speeds. The perforated disc of $0.64 \mathrm{~cm}$ thickness having 48 holes of $1.28 \mathrm{~cm}$ diameter and the nonperforated disc of the same thickness were used. The results of these experiments are reported in Table 1 and shown in Fig. 5.
Factorial experiment: A $5 \times 5 \times 5$ factorial experiment, laid down in a completely randomized split-split-plot design in two blocks, was utilized. The immersion depth of $7.5 \mathrm{~cm}$ was maintained throughout these experiments. The analysis of variance was performed on the $\mathrm{K}_{\mathrm{L}}$ adata using the statistical computer program ANOVA (Sigmaplot, Version 11, Systat Software Inc., California). The results are shown in Table 2. To test the differences among the levels of each factor, Duncan's Multiple Range Test was performed on the $\mathrm{K}_{\mathrm{L}}$ adata.

The results are shown in Table 3-5. The effects of each variable (disc speed, hole diameter or disc thickness) on Ka, while holding all other variables constant, was investigated. The effects of disc speed (using discs of $2.55 \mathrm{~cm}$ thickness, having 28 holes of $1.92 \mathrm{~cm}$ diameter), hole diameter (using discs of 2.55 $\mathrm{cm}$ thickness at a disc speed of $250 \mathrm{rpm}$ ) and disc thickness (using perforated discs having holes of 1.92 $\mathrm{cm}$ diameter at a disc speed of $250 \mathrm{rpm}$ ) are shown in Fig. 6. Changing the values of the fixed parameters yielded similarly shaped curves for the disc speed, hole diameter and disc thickness.

Two disc experiment: The effect of using two discs on $\mathrm{K}_{\mathrm{L}}$ a was investigated at an immersion depth of $7.5 \mathrm{~cm}$. Two discs of 0.32 and $0.64 \mathrm{~cm}$ thickness were used individually and in pairs and the results were compared with those obtained from individual discs of double the thickness. The results are reported in Table 6 and presented in Fig. 7. 
Am. J. Environ. Sci., 7 (2): 108-118, 2011
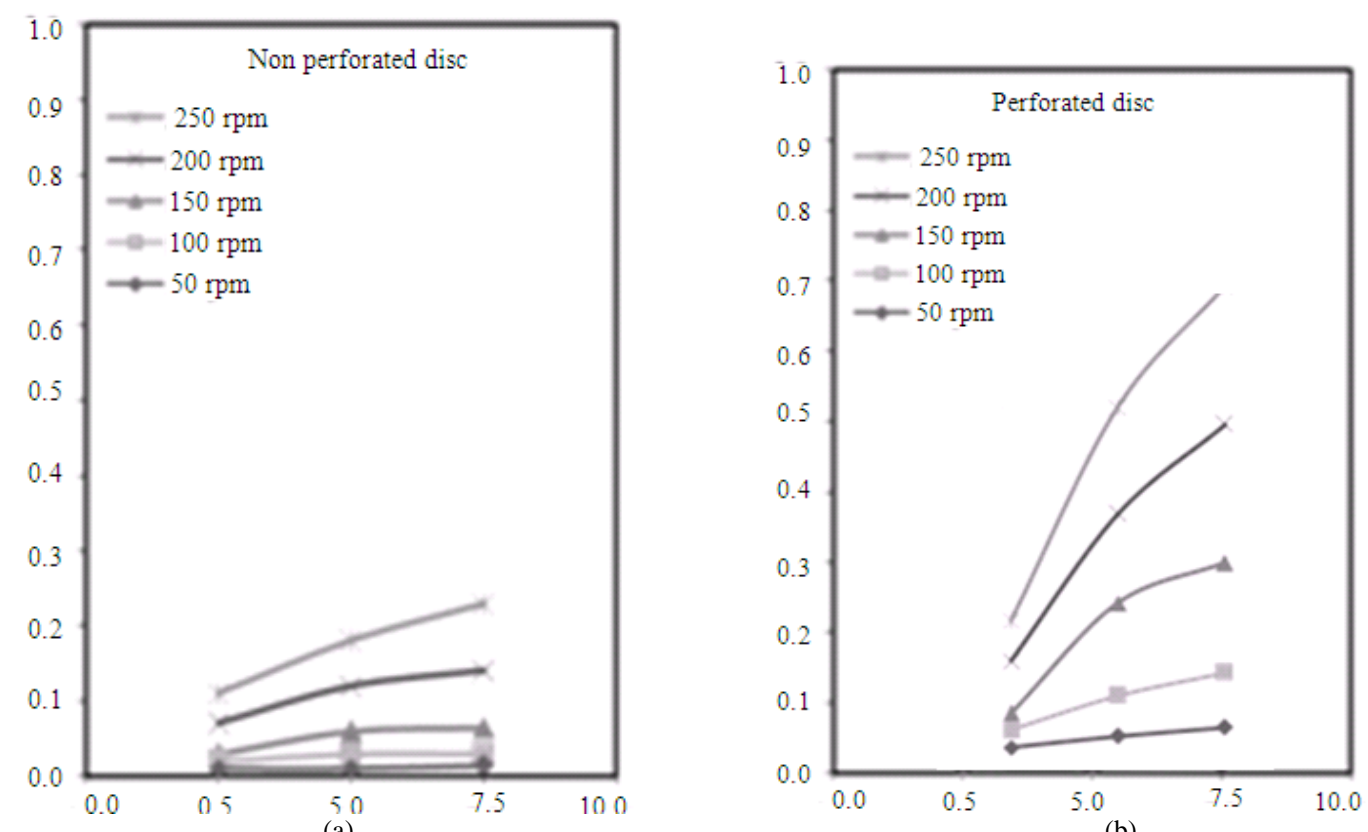

(a)
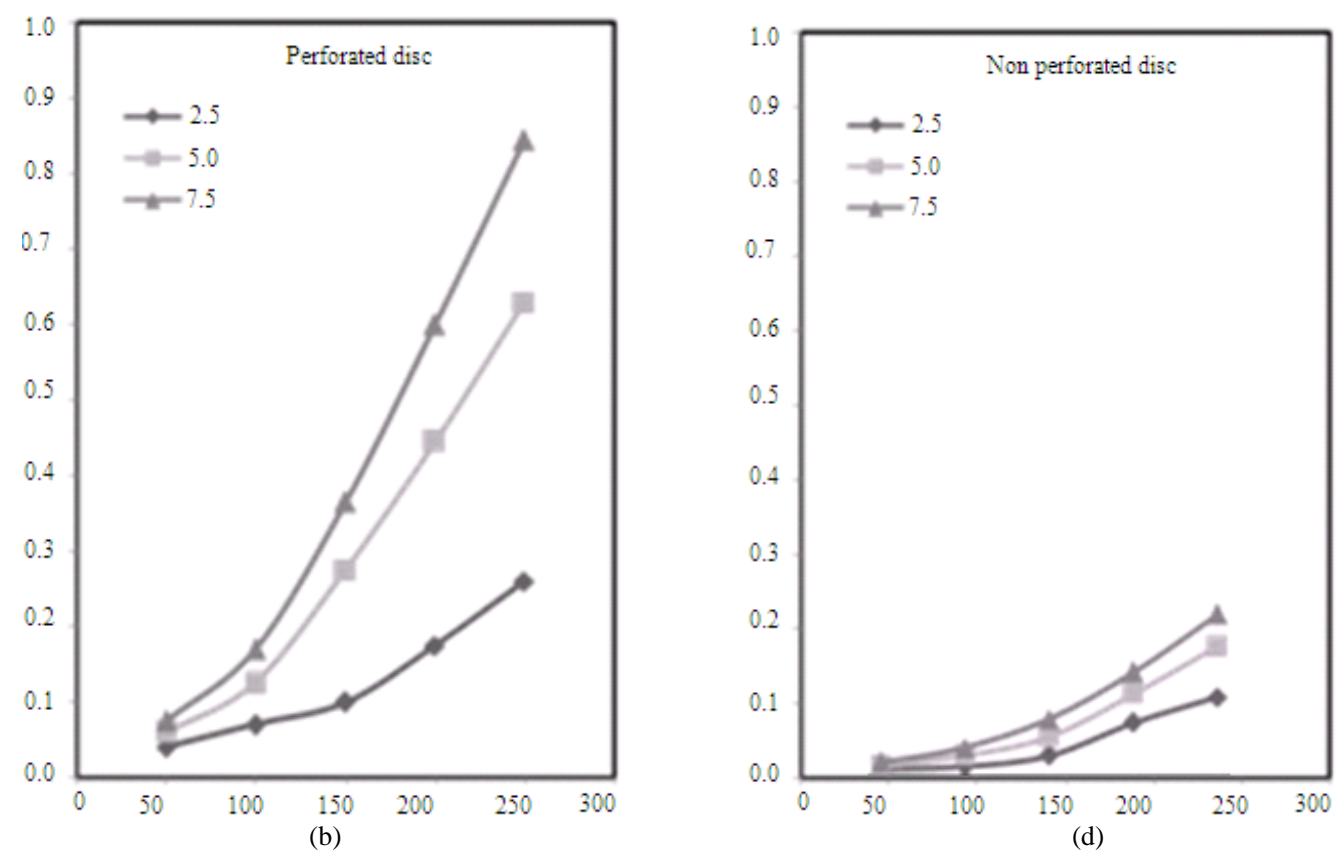

Fig. 5: Effects of immersion depth and disc speed on $\mathrm{K}_{\mathrm{L}}$ a of the $0.64 \mathrm{~cm}$ thick perforated and non-perforated discs

\section{DISCUSSION}

Immersion depth: The immersion depth had a significant effect on $\mathrm{K}_{\mathrm{L}} \mathrm{a}$. Increasing the immersion depth increased $\mathrm{K}_{\mathrm{L}}$ afor both the perforated and nonperforated discs (Table 7). Increasing the immersion depth from 2.5 to $5.0 \mathrm{~cm}$ (100\% increase) increased $\mathrm{K}_{\mathrm{L}}$ aby $30-93 \%$ for the nonperforated disc and by $40-$
$193 \%$ for the perforated one, depending on the rotational speed. A further increase in immersion depth from 5.0-7.5 cm nearly doubled these values.The increase in $\mathrm{K}_{\mathrm{L}}$ awas due to several factors. First, increasing the immersion depth increased the disc area passing through the liquid. About 32, 57 and $77 \%$ of the disc area passed through the liquid for 2.5, 5.0 and $7.5 \mathrm{~cm}$ immersion depths, respectively (Table 8). 
Am. J. Environ. Sci., 7 (2): 108-118, 2011

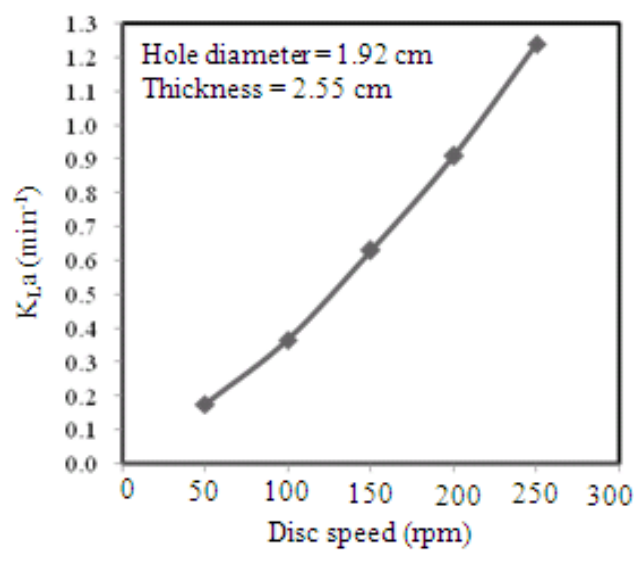

(a)

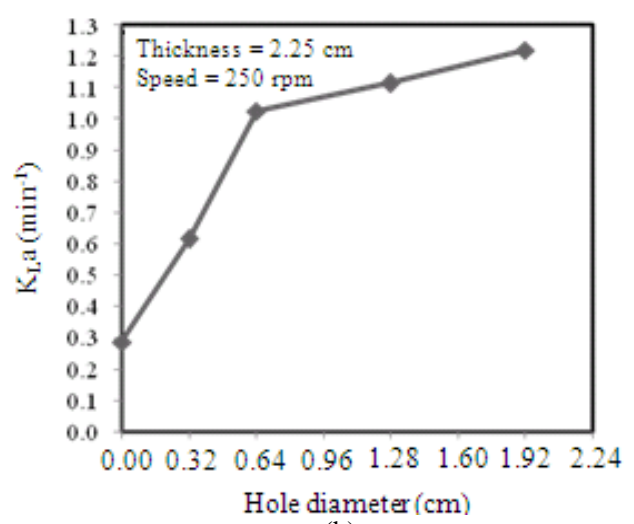

(b)

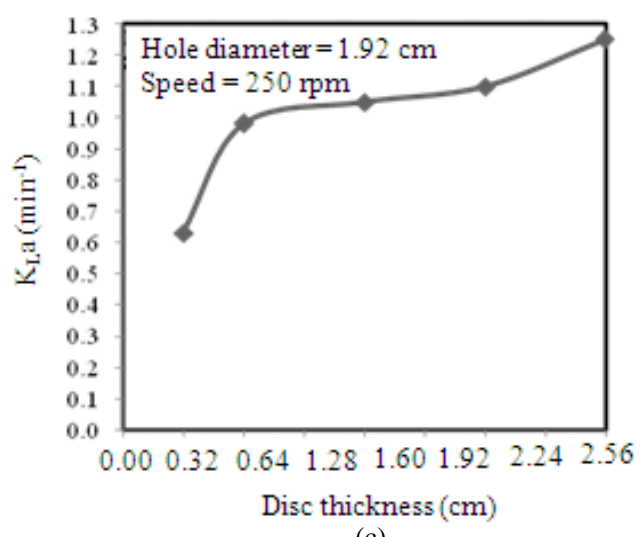

(c)

Fig. 6: The effects of disc speed, hole diameter and disc thickness on the $\mathrm{K}_{\mathrm{L}} \mathrm{a}$.

Second, increasing the immersion depth increased the number of holes passing through the liquid. For immersion depths of 2.5, 5.0 and $7.5 \mathrm{~cm}$, there were 38, 70 and 96 holes passing through the liquid per revolution, respectively. Third, increasing the immersion depth increased the average residence time of the holes and, therefore, presumably the residence time of the bubbles.

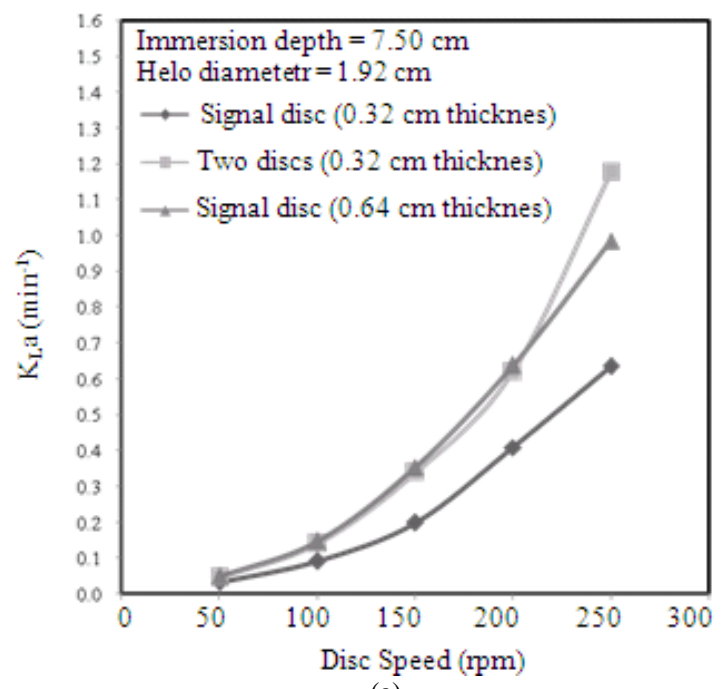

(a)

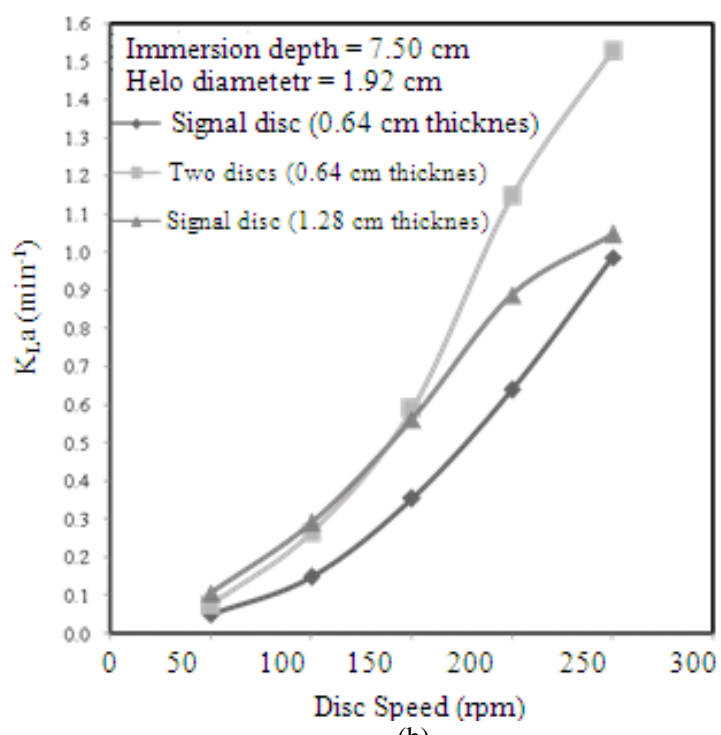

(b)

Fig. 7: Effect of number of discs on disc speed (rpm).

Fourth, increasing the immersion depth increased the extent of the oxygenated and thoroughly mixed layer. The oxygenated layer was 23, 46 and $69 \%$ for the immersion depths of 2.5, 5.0 and 7.5 respectively.

The number of holes $=48$

The hole diameter $=1.28 \mathrm{~cm}$

In this experiment, the effect of disc speed on $\mathrm{K}_{\mathrm{L}}$ awas also extensive. Increasing the disc speed increased $\mathrm{K}_{\mathrm{L}}$ afor both the perforated and nonperforated discs. The rate of increase was dependent on the immersion depth; the greater the depth the more rapid was the increase in $\mathrm{K}_{\mathrm{L}} \mathrm{a}$ (Table 9). 
Am. J. Environ. Sci., 7 (2): 108-118, 2011
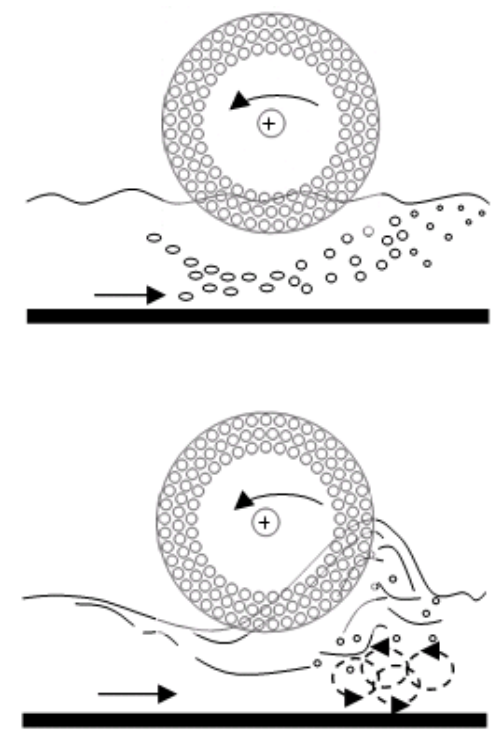

Fig. 8: Formation of air bubbles and eddies in the oxidation ditch

For all disc speeds, the perforated disc had much values compared to those of the nonperforated disc. Increasing the number of holes passing through the liquid increased the number of bubbles in the liquid per unit time, although it decreased the average residence time.

Moulick et al. (2002) found the immersion depth of a paddle wheel aerator to have a significant effect on aeration. Through a series of tests, performed while holding other variables constant, they were able to determine the optimum depth for the paddle wheel system. Thakre et al. (2008) assessed the effects of immersion depth on the oxygenation capacity and power consumption of paddle wheel aerators and $\mathrm{K}_{\mathrm{L}} \mathrm{a}$ $\left(\mathrm{min}^{-1}\right)$ found that increasing immersion depth allowed for a marginal increase in oxygenation capacity and a dramatic rise in power consumption. Thakre et al. (2009) tested the effects of immersion depth on the oxygenation capacity of curved blade aerators and found that as immersion depth was increased from 4.8$7.2 \mathrm{~cm}$ (50\% increase), the oxygen transfer coefficient $\left(\mathrm{K}_{\mathrm{L}} \mathrm{a}\right)$ rose from 8.41-10.93 $\mathrm{h}^{-1}$ (30\% increase) and the power consumption almost doubled (from $69.9 \mathrm{~W}$ to $136 \mathrm{~W})$.

Pasveer (1953) investigated the effect of immersion depth of a $42 \mathrm{~cm}$ diameter brush aerator on the oxygenation capacity and found that when the immersion depth was increased from $5 \mathrm{~cm}$ to $14 \mathrm{~cm}$ (180\% increase), the oxygenation capacity rose from $147 \mathrm{~g} / \mathrm{hr} \mathrm{m}^{3}$ to $391 \mathrm{~g} / \mathrm{hr} \mathrm{m}^{3}$ (166\% increase). AlAhmady (2006) investigated the oxygen transfer capacity in a bench scale subsurface aerator and found that by increasing the water depth the average bubble residence time increased allowing more time for oxygen transfer to occur. As water depth rose from 0.5 $\mathrm{m}$ to $4.6 \mathrm{~m}$ (820\% increase) the oxygen transfer capacity rose from $18-170 \mathrm{~g} \mathrm{~m}^{3 .-1} \mathrm{~h}$ (844\% increase). Gillot et al. (2005) Bayramoglu et al. (2000) developed models to determine oxygen transfer rates in diffused air aeration tanks and found that as water depth increased, the oxygen transfer rate increased. Groves et al. (1992) found that perforated membrane diffusers provided better oxygen transfer than coarse bubble diffusers due to increases in bubble surface area to volume ratio.

Disc speed, thickness and hole diameter: The analysis of variance performed on the data indicated that all three factors (disc speed, hole diameter and disc thickness) had highly significant effects (at 0.0001 level) on $\mathrm{K}_{\mathrm{L}} \mathrm{a}$. All three factors were also significantly interrelated (at the 0.0001 level). The five levels of each factor were found to be significantly different from each other.

For any given combination of disc thickness-hole diameter, increasing the disc speed increased $\mathrm{K}_{\mathrm{L}}$ arapidly. For example, at the best combination (producing highest $\mathrm{K}_{\mathrm{L}} \mathrm{a}$ ) of disc thickness-hole diameter $(2.55 \mathrm{~cm}$ and $1.92 \mathrm{~cm})$, increasing the disc speed from $50-250 \mathrm{rpm}$ (400\% increase) increased $\mathrm{K}_{\mathrm{L}}$ a by $585 \%$ (from 0.18-1.23 $\mathrm{min}^{-1}$ ).

Although the effect of disc thickness on $\mathrm{K}_{\mathrm{L}} \mathrm{a}$ was not as profound as that of disc speed, it was significant. At the best combination of disc speed-hole diameter (250 rpm and $1.92 \mathrm{~cm}$ ), increasing the disc thickness from $0.32-0.64 \mathrm{~cm}$ (100\% increase) increased $\mathrm{K}_{\mathrm{L}}$ aby 55 $\%$. A further increase in the disc thickness up to 2.55 $\mathrm{cm}$ yielded an additional increase in $\mathrm{K}_{\mathrm{L}}$ a of only $39 \%$. The presence of holes and their diameters, showed considerable effects on $\mathrm{K}_{\mathrm{L}} \mathrm{a}$. At the best combination of disc speed-disc thickness (250 rpm and $2.55 \mathrm{~cm}$, respectively), the presence of small holes of $0.32 \mathrm{~cm}$ diameter increased $\mathrm{K}_{\mathrm{L}} \mathrm{a}$ by $116 \%$ over that of the nonperforated disc. Increasing the hole diameter from $0.32-1.92 \mathrm{~cm}$ (500\% increase) resulted in an additional increase in $\mathrm{K}_{\mathrm{L}}$ a of $223 \%$.

Paolini (1986) performed a study on a Rotating Biological Contactor (RBC) aerator used in waste water treatment and found that as the disc speed increased from $3 \mathrm{rpm}$ to $25 \mathrm{rpm}$ (733\% increase) $\mathrm{K}_{\mathrm{L}}$ a increased from 0.11-0.33 $\mathrm{min}^{-1}$ (200\% increase). Moulick et al. (2002) obtained similar results when adjusting mixing speed in a paddle wheel aerator. 
Am. J. Environ. Sci., 7 (2): 108-118, 2011

Table 1: $\mathrm{K}_{\mathrm{La}}\left(\mathrm{min}^{-1}\right)$ at various immersion depths and disc speeds for perforated and non-perforated discs of $0.64 \mathrm{~cm}$ thickness

\begin{tabular}{|c|c|c|c|c|c|c|}
\hline \multirow{3}{*}{$\begin{array}{l}\text { Speed } \\
\text { (rpm) }\end{array}$} & \multicolumn{6}{|c|}{ Immersion depth (cm) } \\
\hline & \multicolumn{2}{|l|}{2.5} & \multicolumn{2}{|l|}{5.0} & \multicolumn{2}{|l|}{7.5} \\
\hline & Non-perforated & Perforated & Non-perforated & Perforated & Non-perforated & Perforated \\
\hline 50 & 0.012 & 0.043 & 0.015 & 0.060 & 0.018 & 0.076 \\
\hline 100 & 0.016 & 0.068 & 0.031 & 0.126 & 0.033 & 0.171 \\
\hline 150 & 0.031 & 0.099 & 0.060 & 0.290 & 0.068 & 0.361 \\
\hline 200 & 0.075 & 0.191 & 0.121 & 0.448 & 0.144 & 0.600 \\
\hline 250 & 0.108 & 0.258 & 0.180 & 0.636 & 0.227 & 0.847 \\
\hline
\end{tabular}

Table 2: Analysis of variance.

\begin{tabular}{|c|c|c|c|c|c|}
\hline Source & Df & Ss & Ms & $\mathrm{F}$ & $\operatorname{Pr}>f$ \\
\hline Total & 249 & 23.27185 & & & \\
\hline Bet. all mpu (rd comb.) & 9 & 5.64887 & & & \\
\hline $\mathrm{R}$ & 1 & 0.00003 & 0.00003 & 1.05 & 0.3665 \\
\hline D & 4 & 5.64873 & 1.41218 & 52915.19 & 0.0001 \\
\hline $\begin{array}{l}\text { Error-a }\left(\mathrm{r}^{*} \mathrm{~d}\right) \\
\text { within all mpu }\end{array}$ & 4 & 0.00011 & 0.00003 & & \\
\hline $\begin{array}{l}\text { (Ts comb. in ra comb.) } \\
\text { spu in all mpu }\end{array}$ & 240 & 17.62298 & & & \\
\hline (tin ra comb.) & 40 & 1.47002 & & & \\
\hline $\mathrm{T}$ & 4 & 0.71535 & 0.17884 & 719.65 & 0.0001 \\
\hline $\mathrm{D} * \mathrm{~T}$ & 16 & 0.74970 & 0.04686 & 188.55 & 0.0001 \\
\hline Error-b $\left(\mathrm{r}^{*} \mathrm{t}(\mathrm{d})\right)$ & 20 & 0.00497 & 0.00025 & & \\
\hline sspu in all spu & 200 & 16.15296 & & & \\
\hline $\mathrm{S}$ & 4 & 13.62288 & 3.40572 & 16364.85 & 0.0001 \\
\hline $\mathrm{D}^{*} \mathrm{~s}$ & 16 & 2.08040 & 0.13002 & 624.78 & 0.0001 \\
\hline $\mathrm{T}^{*} \mathrm{~s}$ & 16 & 0.19872 & 0.01242 & 59.68 & 0.0001 \\
\hline $\mathrm{D} * \mathrm{t} * \mathrm{~s}$ & 64 & 0.23015 & 0.00360 & 17.28 & 0.0001 \\
\hline error-c ( $\mathrm{r}^{*} \mathrm{~s}$ in dt comb.) & 100 & 0.02081 & 0.00021 & & \\
\hline
\end{tabular}

Table 3: Mean values of as affected by disc speed

\begin{tabular}{llll}
\hline Speed $(\mathrm{rpm})\left(\mathrm{min}^{-1}\right)$ & $\mathrm{N}$ & $\mathrm{K}_{\mathrm{L}} \mathrm{a}$ & Grouping \\
\hline 50 & 50 & 0.0557 & $\mathrm{~A}$ \\
100 & 50 & 0.1278 & $\mathrm{~B}$ \\
150 & 50 & 0.2711 & $\mathrm{C}$ \\
200 & 50 & 0.4579 & $\mathrm{D}$ \\
250 & 50 & 0.6999 & $\mathrm{E}$ \\
\hline
\end{tabular}

Table 4: Mean values of $\mathrm{K}_{\mathrm{L}}$ as affected by disc thickness

\begin{tabular}{llll}
\hline Thickness $(\mathrm{cm})\left(\mathrm{min}^{-1}\right)$ & $\mathrm{N}$ & $\mathrm{K}_{\mathrm{L}} \mathrm{a}$ & Grouping \\
\hline 0.32 & 50 & 0.2417 & $\mathrm{~A}$ \\
0.64 & 50 & 0.2915 & $\mathrm{~B}$ \\
1.28 & 50 & 0.3293 & $\mathrm{C}$ \\
1.92 & 50 & 0.3498 & $\mathrm{D}$ \\
2.55 & 50 & 0.4001 & $\mathrm{E}$ \\
\hline
\end{tabular}

Table 5: Mean values of $\mathrm{K}_{\mathrm{L}}$ as affected by hole diameter

\begin{tabular}{lllllll}
\hline $\begin{array}{l}\text { Speed } \\
\text { (rpm) }\end{array}$ & $-17--1$ & \multicolumn{5}{c}{ Disc thickness } \\
& 0.32 & $0.32 *$ & 0.64 & 0.64 & $0.64 *$ & 1.28 \\
& & & & & & \\
\hline 50 & 0.033 & 0.046 & 0.050 & 0.050 & 0.073 & 0.105 \\
100 & 0.092 & 0.140 & 0.148 & 0.148 & 0.263 & 0.291 \\
150 & 0.200 & 0.339 & 0.354 & 0.354 & 0.588 & 0.562 \\
200 & 0.410 & 0.620 & 0.639 & 0.639 & 1.146 & 0.887 \\
250 & 0.635 & 1.176 & 0.986 & 0.986 & 1.526 & 1.047 \\
\hline
\end{tabular}

*Two discs of the specified thickness
Table 6: The effects of disc speed and disc thickness on $\mathrm{K}_{\mathrm{L}} \mathrm{a}\left(\mathrm{min}^{-1}\right)$ using hole diameter of $1.92 \mathrm{~cm}$ at $7.5 \mathrm{~cm}$ immersion depth

\begin{tabular}{llll}
\hline $\begin{array}{l}\text { Hole diameter } \\
(\mathrm{cm})\end{array}$ & $\mathrm{N}$ & $\mathrm{K}_{\mathrm{L}} \mathrm{a}\left(\mathrm{min}^{-1}\right)$ & Grouping \\
\hline 0.00 & 50 & 0.1045 & $\mathrm{~A}$ \\
0.32 & 50 & 0.2058 & $\mathrm{~B}$ \\
0.64 & 50 & 0.3436 & $\mathrm{C}$ \\
1.28 & 50 & 0.4455 & $\mathrm{D}$ \\
1.92 & 50 & 0.5129 & $\mathrm{E}$ \\
\hline
\end{tabular}

Table 6: Percentage increase in $\mathrm{K}_{\mathrm{L}} \mathrm{a}$ due to increase in immersion depth, at various disc speeds

Increase in Immersion Depth

\begin{tabular}{|c|c|c|c|c|}
\hline \multirow{2}{*}{$\begin{array}{l}\text { Speed } \\
\text { (rpm) }\end{array}$} & \multicolumn{2}{|c|}{ (from 2.5 to $5.0 \mathrm{~cm}$ ) } & \multicolumn{2}{|c|}{ (from 5.0 to $7.5 \mathrm{~cm}$ ) } \\
\hline & Non-perforated & Perforated & Non-perforated & Perforated \\
\hline 50 & 30 & 40 & 56 & 77 \\
\hline 100 & 92 & 85 & 108 & 150 \\
\hline 150 & 93 & 193 & 120 & 264 \\
\hline 200 & 61 & 134 & 92 & 213 \\
\hline 250 & 67 & 147 & 111 & 229 \\
\hline
\end{tabular}

Clarke et al. (2006) tested the effects of alkalinity on bioreactor and found that the effects of alkalinity were tied to the speed of the impeller. The addition of alkalinity increased $\mathrm{K}_{\mathrm{L}} \mathrm{a}$ at speeds above $300 \mathrm{rpm}$ and reduced $\mathrm{K}_{\mathrm{L}} \mathrm{a}$ at speeds below300 rpm. 
Am. J. Environ. Sci., 7 (2): 108-118, 2011

Table 7: The effect of immersion depth on the disc area passing through the liquid, the number of holes per revolution and the thickness of the oxygenated layer

\begin{tabular}{lllll}
\hline $\begin{array}{l}\text { Immersion } \\
\text { depth }\end{array}$ & $\begin{array}{l}\text { Disc area passing } \\
\text { through liquid }\end{array}$ & $\begin{array}{l}\text { Number of } \\
\text { holes per } \\
\text { revolution }\end{array}$ & $\begin{array}{l}\text { Oxygenated } \\
\text { layer } \\
(\%)\end{array}$ \\
\hline 2.5 & 208 & 32 & 38 & 23 \\
5.0 & 377 & 57 & 70 & 46 \\
7.5 & 506 & 77 & 96 & 69 \\
\hline
\end{tabular}

Table 8: Percentage increase in $\mathrm{K}_{\mathrm{L}} \mathrm{a}$ due to the presence of holes, at various immersion depths and disc speeds

\begin{tabular}{llll}
\hline & Immersion depth (cm) & \\
$\begin{array}{l}\text { Speed } \\
(\mathrm{rpm})\end{array}$ & $--\mathrm{cm}$ & 5.0 & 7.5 \\
\hline 50 & 272 & 304 & 323 \\
100 & 335 & 320 & 424 \\
150 & 219 & 383 & 428 \\
200 & 157 & 271 & 317 \\
250 & 140 & 254 & 272 \\
\hline
\end{tabular}

Alkalinity is known to improve turbulence, surface reaction properties and the oxygenation capacity.

Double disc: For all aerator discs (single and double), increasing the disc speed increased $\mathrm{K}_{\mathrm{L}}$ arapidly. Increasing the disc speed from $50 \mathrm{rpm}$ to $250 \mathrm{rpm}$ (400\% increase) increased $\mathrm{K}_{\mathrm{L}}$ aby $583-1824 \%$ for single aerator discs and by 1990-2456 \% for double aerator discs, depending on the disc thickness. It was observed that $\mathrm{K}_{\mathrm{L}} \mathrm{a}$ values obtained from a double aerator disc of $0.32 \mathrm{~cm}$ thickness (two discs of $0.32 \mathrm{~cm}$ thickness each, spaced at $2.5 \mathrm{~cm}$ and operating in parallel) were similar to those obtained with the single disc of $0.64 \mathrm{~cm}$ thickness over most of the speed range; it was however, 19 percent greater at $250 \mathrm{rpm}$. For the double aerator disc of $0.64 \mathrm{~cm}$ thickness, at lower speeds (50-150 rpm) $\mathrm{K}_{\mathrm{L}}$ a values were lower than those of single discs of $1.28 \mathrm{~cm}$ thickness but they were considerably greater at higher speeds (up to $46 \%$ higher at $250 \mathrm{rpm}$ ). No reports were found in the literature about the use of multiple discs except that of Drews et al. (1972) in which they were able to adjust the oxygenation capacity by varying the number of discs on a single shaft.

Visual observations: High speed movies were taken during an aeration test at various disc speeds in order to gain a better understanding of the physical processes involved in the oxygen transfer. The films were analyzed frame by frame on a photo optical data analyzer which gave a good picture of the liquid and air bubble movement. Three mechanisms are believed to contribute simultaneously to the process of oxygen transfer: (a) bubble aeration, (b) eddy aeration and (c) surface aeration.

The holes of the disc had a great effect on the addition of bubbles and creation of turbulence in the liquid. The bubbles were formed when the disc entered the liquid and the water replaced the air trapped in the holes. The bubbles were then detached from the disc and continue with the fluid as shown in Fig. 8a. The oxygen transfer then occurs from the air bubbles into liquid phase through the gas-liquid interface. Bubbles with a higher surface area to volume ratio will increase oxygen transfer (Waites, 2008). Therefore, a large number of small bubbles is more desirable than a small number of large bubbles of the same total volume. Ippen et al. (1954) found that smaller bubbles, distributed in a vertical water

The disc also serves as an agitator. The liquid was caught by the edges of the holes and began to form eddies. As the disc rotated and holes left the liquid, a mass of eddies was brought above the surface of the liquid as shown in Fig. 8b. These eddies are considered as continually exposing fresh liquid surface to the air, then gliding swiftly away and mixing into the bulk of liquid. During the exposure of any portion of the liquid to air, transfer of oxygen occurs by molecular diffusion. The rate of production of fresh eddies was a function of the disc rotational speed. Deglon et al. (1998) stated that intermediate and high frequency eddies are better able to cause bubble breakup. They found that spinning nonperforated discs tend to generate low frequency eddies and recommended that spinning discs should be modified by adding grooves or cuts to the edges of discs to improve bubble breakup. In this study, the larger hole diameter and higher speed created high frequency eddies with improved bubble breakup and higher oxygen transfer. Oxygen transfer, from the atmosphere to the liquid body, may have also taken place at the liquid surface in the ditch due to the movement of water. The dissolved oxygen concentration of the surface layer would be higher than that of the bottom layer so that oxygen was transferred downwards. Eckenfelder (1959) found that surface aeration is the result of bubble breakup and the velocity gradients present at the liquid air interface. Increasing the disc speed increased water velocity at the surface layer and improved the oxygen transfer rate.

\section{CONCLUSION}

The effects of immersion depth, disc speed, disc thickness, disc perforation and hole diameter on the oxygen transfer coefficient of disc aerators in an oxidation ditch were investigated. It was found that disc 
speed had the most significant effect on $\mathrm{K}_{\mathrm{L}} \mathrm{a}$ with the immersion depth and hole diameter both showing strong effects as well. While disc thickness had a significant effect on $\mathrm{K}_{\mathrm{L}} \mathrm{a}$ it was not as strong as other parameters. There were also significant interactions between these parameters. Increasing any of the parameters resulted in an increase in $\mathrm{K}_{\mathrm{L}} \mathrm{a}$. In all cases, especially those at higher disc speeds, perforated discs caused significant increases in $\mathrm{K}_{\mathrm{L}}$ a when compared to nonperforated discs. Increasing the number of coaxially rotating discs was also seen to have a significant effect on $\mathrm{K}_{\mathrm{L}} \mathrm{a}$. However, the effect of adding a second disc was comparable to using a single disc of double the thickness at lower disc speeds while at disc speeds higher than $200 \mathrm{rpm}$ doubling the thickness of a single disc had less of an effect on $\mathrm{K}_{\mathrm{L}}$ a than adding a second disc. The visual observations, made with the assistance of high speed film, indicated that bubble aeration and eddy aeration, created by disc rotation, were the prevalent oxygen transfer mechanisms. Surface aeration at the liquid-air interface may also have played a smaller role in oxygenating the system.

\section{ACKNOWLEDGEMENT}

This research was supported by the National Science and Engineering Research Council (NSERC) of Canada.

\section{REFERENCES}

Al-Ahmady, K.K., 2006. Analysis of oxygen transfer performance on sub-surface aeration systems. Intern. J. Environ. Rese. Pub. Heal., 3: 301-308. DOI: 10.3390/IJERPH2006030037

Bayramoglu, M., A. Cakici and T. Tekin, 2000. Modelling of oxygen transfer rate in diffused-air aeration tanks. Proc. Saf. Enviro. Prote., 78: 209212. DOI:10.1205/095758200530655

Bicudo, J. and I.F. Svoboda, 1995. Effect of intermittent-cycle extended aeration treatment on the fate of carbonaceous material in pig slurry. Biores. Technol., 54: 53-62. DOI: 10.1016/09608524(95)00114-X

Carta, F., P. Alvarez, F. Romero and J. Pereda, 1999. Aerobic purification of dairy wastewater in continuous regime; reactor with support. Process Biochemistry, 34: 613-619. DOI: 10.1016/S00329592(98)00133-2

Clarke, K.G., P.C. Williams, M.S. Smit and S.T.L. Harrison, 2006. Enhancement and repression of the volumetric oxygen transfer coefficient through hydrocarbon addition and its influence on oxygen transfer rate in stirred tank bioreactors. Bioch. Eng. J., 28: 237-242. DOI: 10.1016/J.BEJ.2005.11.007

Deglon, D.A., C.T. O'Connor and A.B. Pandit, 1998. Efficacy of a spinning disc as a bubble break-up device. Chem. Eng. Sci., 53: 59-70. DOI: 10.1016/S0009-2509(97)00309-6

Drews, R.J.L.C., W.M. Malan, P.G.J. Meiring and B. Moffatt, 1972. The orbal extended aeration activated sludge plant. Wat. Poll. Con. Feder., 44: 221-231. http://www.jstor.org/pss/25037300

Eckenfelder, W.W., 1959. Factors affecting the aeration efficiency of sewage and industrial wastes. Sew. Indu. $\quad$ Wast., $\quad 31$ 60-70. http://www.jstor.org/pss/25033795

Fritsche, W. and M. Hofrichter, 2008. Aerobic Degradation by Microorganisms. In Biotechnology Set, Second Edition (eds H.-J. Rehm and G. Reed), Wiley-VCH Verlag GmbH, Weinheim, Germany. DOI: 10.1002/9783527620999.ch6m

Ghaly, A.E. and R. Kok, 1988. The effect of sodium sulfite and cobalt chloride on the oxygen transfer coefficient. Applied Bioch. Biotechnol., 19: 259270. DOI: $10.1007 / \mathrm{BF} 02921498$

Ghaly, A.E., 1982. Minimal Aeration of Swine Manure for Odor Control, unpublished Ph.D. Thesis, McGill University, Montreal, Quebec.

Gillot, S., S. Capela-Marsal, M. Roustan and A. Heduit, 2005. Predicting oxygen transfer of fine bubble diffused aeration systems-model issued from dimensional analysis. Water Rese., 39: 13791387. DOI: 10.1016/J.WATRES.2005.01.008

Groves, K.P., G.T. Daigger, T.J. Simpkin, D.T. Redmon and L. Ewing, 1992. Evaluation of oxygen transfer efficiency and alpha-factor on a variety of diffused aeration systems. Water Environ. Res., 64: 691-698. http://www.jstor.org/pss/25044209

Ippen, A.T., C.E. Carver and W.E. Dobbins, 1954. Basic factors of oxygen transfer in aeration systems [with discussion]. Sew. Indus. Wast., 26: 813-829. http://www.jstor.org/pss/25032513

Juteau, P., D. Tremblay, C.B. Ould Moulaye, J.G. Bisaillon and R. Beaudet, 2004. Swine waste treatment by self-heating aerobic thermophilic bioreactors. Water Res., 38: 539-546. DOI: 10.1016/J.WATRES.2003.11.001

Kargi, F., M.L. Shuler, R. Vashon, H.W. Seeley Jr, A. Henry and R.E. Austic, 1980. Continuous aerobic conversion of poultry waste into single-cell protein using a single reactor: kinetic analysis and determination of optimal conditions. Biotechnol. Bioen., $\quad 22$ : $1567-1600 . \quad$ DOI: 10.1002/BIT.260220805 
Am. J. Environ. Sci., 7 (2): 108-118, 2011

Loehr, R.C. 1971. Alternatives for the treatment and disposal of animal wastes. Water Pollu. Cont. Fede., $\quad$ 43: 668-678. http://www.jstor.org/pss/25037364

Mohaibes, M. and H. Heinonen-Tanski, 2004. Aerobic thermophillic treatment of farm slurry and food wastes. Biores. Technol., 95: 245-254. DOI: 10.1016/J.BIORTECH.2004.02.022' http://www.sciencedirect.com/science?

Moulick, S., B.C. M. and S. Bandyopadhyay, 2002. Prediction of aeration performance of paddle wheel aerators. Aquacul. Eng., 25: 217-237. DOI: 10.1016/S0144-8609(01)00087-5

Murray, I., J.W. Parsons and K. Robinson, 1975. Inter-relationships between nitrogen balance, $\mathrm{pH}$ and dissolved oxygen in an oxidation ditch treating farm animal waste. Water Res., 9: 25-30. DOI: 10.1016/0043-1354(75)90148-7

Nemerow, N.L., 2007. Industrial Waste Treatment: Contemporary Practice and a Vision for the Future. Burlington, MA: Elsevier Inc.

Ogilvie, J.R. and K. Kingsbury, 1974. The disc aerator in animal waste processing. CSAE study no. 74216. Ottawa, Ontario.

Otawa, K., R. Asano, Y. Ohba, T. Sasaki and E. Kawamura et al., 2006. Molecular analysis of ammonia-oxidizing bacteria community in intermittent aeration sequencing batch reactors used for animal wastewater treatment. Environ. Microbiol., 8: 1985-1996. DOI: 10.1111/J.14622920.2006.01078.X

Paolini, A.E., 1986. Effect of biomass on oxygen transfer in RBC systems. Water Poll. Cont. Feder., 58: 306-311. http://www.jstor.org/pss/25042906

Pasveer, A., 1953. Research on activated sludge: II. experiments with brush aeration. Sewage Indus. Wast., $\quad$ 25: 1397-1404. http://www.jstor.org/pss/25032354
Thakre, S.B., L.B. Bhuyar and S.J. Deshmukh, 2008. Effect of different configurations of mechanical aerators on oxygen transfer and aeration efficiency with respect to power consumption. Intern. J. Mecha., Indu. Aeros. Engine., 2: 100-108. http://www.akademik.unsri.ac.id/download/journal /files/waset/v2-2-15-17.pdf

Thakre, S.B., L.B. Bhuyar and S.J. Deshmukh, 2009. Oxidation ditch process using curved blade rotor as aerator. Intern. J. Envir. Scie. Technol., 6: 113-122. http://www.emro.who.int/imemrf/ijes_2009_6_1_1 13.pdf

Tiquia, S.M. and N.F. Tam, 2002. Characterization and composting of poultry litter in forced aeration piles. Proc. Bioche., 37: 869-880. DOI: 10.1016/S0032-9592(01)00274-6

Ushikubo, A., M. Yoshimura, M. Kato and G. Oyama et al., 1991. Livestock waste treatment in a double channel oxidation ditch. Agric. Ecosy. Environ., 36: 59-74. DOI: 10.1016/0167-8809(91)90036-W

Waites, M.J. 2008. Industrial Microbiology: An Introduction.7th Edn. Wiley-Blackwell, Malden, MA, ISBN: 0632053070, pp: 288.

Zhang, Z., J. Zhu, K. Park, 2006. A bench-scale aeration study using batch reactors on swine manure stabilization to control odour in post treatment storage. Water Res., 40: 162-174. DOI: 10.1016/J.WATRES.2005.11.004

Zhu, N., C. Deng, Y. Xiong and H. Qian, 2004. Performance characteristics of three aeration systems in the swine manure composting. Biore. Technol., 95: 319-326. DOI: 10.1016/J.BIORTECH.2004.02.021 